\section{Transovarial transmission and finding of Trypanosoma rhipicephalis in the hemolymph of Rhipicephalus sanguineus sensu lato}

\author{
Transmissão transovariana e achado de Trypanosoma \\ rhipicephalis na hemolinfa de Rhipicephalus sanguineus sensu lato
}

BJ $\mathbf{M}$

p-ISSN 0100-2430

e-ISSN 2527-2179

\begin{abstract}
Yasmim Kaulich ${ }^{1}$ (D), Carolina Marotta Ribeiro ${ }^{2}$ (D) , Jaqueline Rodrigues de Almeida Valim² (D) , Juliana Ferreira dos Santos $^{3}$ (D) , Thays Figueiroa dos Santos ${ }^{4}$ (1) , Cláudia Bezerra da Silva ${ }^{5}$ (1) \& Adivaldo Henrique da Fonseca ${ }^{6}$ (1)

'Veterinary Student, Scientific Iniciation Scholarship FAPERJ, Awarded the Tokarnia Research Prize - SEMEV, IV. Departamento de Epidemiologia e Saúde Pública, Universidade Federal Rural do Rio de Janeiro - UFRRJ Seropédica, RJ, Brasil.

${ }^{2}$ Post Doctorate. Programa de Pós-graduação em Ciências Veterinárias, Universidade Federal Rural do Rio de Janeiro - UFRRJ, Seropédica, RJ, Brasil

${ }^{3}$ Quemistry Student, Scholarship. Departamento de Epidemiologia e Saúde Pública, Universidade Federal Rural do Rio de Janeiro UFRRJ, Seropédica, RJ, Brasil

${ }^{4}$ Veterinary Student, Scientific Iniciation Scholarship PIBIC. Departamento de Epidemiologia e Saúde Pública, Universidade Federal Rural do Rio de Janeiro - UFRRJ, Seropédica, RJ, Brasil

${ }^{5}$ Veterinary, Dr. Departamento de Parasitologia Animal, Universidade Federal Rural do Rio de Janeiro - UFRRJ, Seropédica, RJ, Brasil ${ }^{6}$ Veterinary, Dr, CNPQ Productivity Scholarship. Departamento de Epidemiologia e Saúde Pública, Universidade Federal Rural do Rio de Janeiro - UFRRJ, Seropédica, RJ, Brasil
\end{abstract}

\begin{abstract}
Trypanosoma rhipicephalis is a species isolated from Rhipicephalus microplus ticks collected from native bovine Seropédica, in the state of Rio de Janeiro. This study aimed to investigate the interaction of the tick Rhipicephalus sanguineus s. l. with T. rhipicephalis by in vitro artificial feeding. Eight females of $R$. sanguineus s. l. partially fed on rabbits. Tick infection was performed by an artificial feeding system using plastic tips for 12 hours. Canine blood used for feeding the ticks test group was previously infected with $T$. rhipicephalis $10^{8} / \mathrm{mL}$. The hemolymph smear test was performed in all females after experimental infection. The daily posture was collected and organized in pools of each female per posture day. The eggs were divided into three groups, the first group for eggs PCR, the second for hatching and larval PCR, and the third group of eggs for isolation in cell culture. The evaluation of the presence of DNA in the macerated eggs of experimentally infected ticks showed two positive PCR samples. The evaluation of the presence of DNA in experimentally infected females showed all samples tested positive. For the hemolymph test, tick number 7 presented epimastigote developmental forms and amastigotes of T. rhipicephalis. Experimental infection by artificial feeding proved to be a suitable tool to study the interaction of T. rhipicephalis in $R$. sanguineus s. l. ticks. The results show the transovarial transmission of T. rhipicephalis by R. sanguineus S. $l$., as well as the interaction of the protozoan in the organism of this tick species.
\end{abstract}

Keywords: ticks, artificial feeding, trypanosomatids.

\section{Resumo}

Trypanossoma rhipicephalis é uma espécie isolada do carrapato Rhipicephalus microplus coletado de bovino nativo de Seropédica, estado do Rio de Janeiro. O presente estudo teve como objetivo investigar a interação do carrapato Rhipicephalus sanguineus s.l. com T. rhipicephalis por meio da alimentação artificial in vitro. Foram utilizadas 8 fêmeas de R. sanguineus s. l. parcialmente alimentadas em coelhos. A infecção dos carrapatos foi realizada por meio de um sistema de alimentação artificial utilizando ponteiras plásticas por um período de 12 horas. O sangue canino utilizado para alimentar os carrapatos do grupo teste foi previamente infectado com $10^{8}$ de T. rhipicephalis $/ \mathrm{mL}$. O teste de esfregaço de hemolinfa foi realizado em todas as fêmeas após a infecção experimental. A postura diária foi coletada e organizada em pools de cada fêmea por dia de postura. Os ovos foram separados em 3 grupos, sendo o primeiro grupo para a PCR dos ovos, o segundo para sua eclosão e PCR das larvas e o terceiro grupo para isolamento dos ovos em cultivo celular. A avaliação da presença de DNA no macerado de ovos dos carrapatos infectados
How to cite: Kaulich, Y., Ribeiro, C. M.; Valim, J. R. A.; Santos, J. F.; Santos, T. F.; Silva, C. B.; Fonseca, A. H. (2019). Transovarial transmission and finding of Trypanosoma rhipicephalis in the hemolymph of Rhipicephalus sanguineus sensu lato. Brazilian Journal of Veterinary Medicine, 41 el06819. doi: 10.29374/2527-2179.bjvm106819

Financial support: This study was financed in part by the Coordenação deAperfeiçoamento de Pessoal de Nível Superior - Brasil (CAPES) Finance Code 001 FAPERJ.

Conflict of interests: No conflict of interests declared concerning the publication of this article.

Received: July 30, 2019.

Accepted: August 26, 2019

The study was carried out at Parasitic Diseases Laboratory, Department of Epidemiology and Public Health of the Veterinary Institute (IV), Universidade Federal Rural do Rio de Janeiro (UFRRJ), located in building 1 of the Veterinary Institute, in the municipality of Seropédica, Rio de Janeiro.

\section{*Correspondence}

Adivaldo Henrique da Fonseca

Universidade Federal Rural do Rio de Janeiro,

Departamento de Epidemiologia e Saúde

Pública

Rodovia BR 465, Km 7

CEP 23897-000 - Seropédica (RJ), Brasil

E-mail: adivaldo@ufrrj.br

aThis article was awarded the Tokarnia Research Prize / UFRRJ.

Copyright Kaulich et al. This is an Open Access article distributed under the terms of the Creative Commons Attribution Non-Commercial License which permits unrestricted non-commercial use, distribution, and reproduction in any medium provided the original work is properly cited. 
experimentalmente mostrou duas amostras positivas na PCR. A avaliação da presença de DNA nas fêmeas infectadas experimentalmente mostrou todas as amostras do grupo teste positivas. Pelo teste de hemolinfa, o carrapato número 7 apresentou formas evolutivas epimastigota e amastigotas de $T$. rhipicephalis. A infecção experimental por meio da alimentação artificial mostrou-se uma ferramenta adequada para estudar a interação de T. rhipicephalis em $R$. sanguineus s. l. Os resultados comprovam a transmissão transovariana do T. rhipicephalis por R. sanguineus s. l., assim como a interação do protozoário no organismo desta espécie de carrapato.

Palavras-chave: carrapato, alimentação artificial, tripanosomatídeos.

\section{Introduction}

Parasites of the genus Trypanosoma are unicellular and flagellated microorganisms belonging to the Trypanosomatidae family with wide geographical distribution. Hematophagous arthropods act as biological and mechanical vectors for different species of this family, infecting a wide variety of hosts, ranging from plants to animals, vertebrates and invertebrates (Hoare, 1972); (Morzaria et al., 1986).

Ticks, as blood feeders, are predisposed to the ingestion of a variety of parasites during feeding and have been proposed as vectors for Trypanosoma species (Morzaria et al., 1986); (Burgdorfer et al., 1973); and (Krige et al., 2019). Artificial tick feeding is an important tool for studying the transmission of pathogens in the absence of vertebrate hosts (Chabaud, 1950); (Valim et al., 2017). Cell culture of tick embryonic cells is an important tool for studying the interaction between cells of these arthropods and pathogens transmitted by them because it may help define the complex nature of the host-vector-pathogen relationship (Bell-Sakyi et al., 2007).

Trypanosoma rhipicephalis Marotta et al. (2018) is a species isolated from R. microplus ticks from native Seropédica cattle (Marotta et al., 2018). Little is known about its biological cycle; aspects related to possible pathogenesis and interaction with other species are unknown (Marotta et al., 2018).

The present study aims to investigate the interaction of Rhipicephalus sanguineus sensu lato and T. rbipicephalis by means of artificial feeding of ticks.

\section{Material and methods}

The experiments were performed at the Parasitic Diseases Laboratory of the Department of Epidemiology and Public Health of the Veterinary Institute (IV) of the Federal Rural University of Rio de Janeiro (UFRRJ), located in building 1 of the Veterinary Institute, in the municipality of Seropédica, Rio de Janeiro.

Eight females of $R$. sanguineus s. l. from the tick colony maintained at the Parasitic Disease Laboratory of the UFRRJ were partially fed on rabbits, following the methodology described by Valim et al. (2017). Two groups (G) were formed, one specimen was fed uninfected blood (G1 control), and seven were fed infected blood (G2 test). Tick infection was performed by an artificial feeding system using plastic tips (Figure 1) for a period of 12 hours following the procedures described by Valim et al. (2017). Blood used for artificial tick feeding was collected aseptically from the dog's cephalic vein by the Vacutainer ${ }^{\circledR}$ system coupled to a $5 \mathrm{~mL}$ tube containing citrate anticoagulant. The material was labelled and stored under refrigeration at $4{ }^{\circ} \mathrm{C}$ for up to 24 hours.

To perform Trypanosoma blood infection, the dog's blood serum complement system was previously inactivated so as not to cause reactions with the inoculated agent. For inactivation of the complement system, collected blood was centrifuged at $5000 \mathrm{rpm}$ for 10 minutes. Then, the supernatant was kept for 40 minutes in $256^{\circ} \mathrm{C}$ water bath. The pellet was resuspended with PBS in a volume equivalent to the initial blood volume. Then two washes with PBS were performed. After the serum reached room temperature $\left(26^{\circ} \mathrm{C}\right)$, it was homogenized with the red blood cells. Canine blood used to feed $\mathrm{G} 2$ test ticks was previously infected with $10^{8}$ T. rhipicephalis/mL.

The hemolymph smear test was performed in all females after the experimental infection, being evaluated from the first DPI (the day after infection) until the posture, i.e., 13th DPI. The females used were kept frozen for later DNA extraction and PCR analysis. Hemolymph samples collected from the distal (tarsal and/or tibial) section of one or more teleogin legs were deposited on a glass slide, identified, fixed for three minutes in methanol and stained by the Giemsa 10\% method for 25 minutes. 


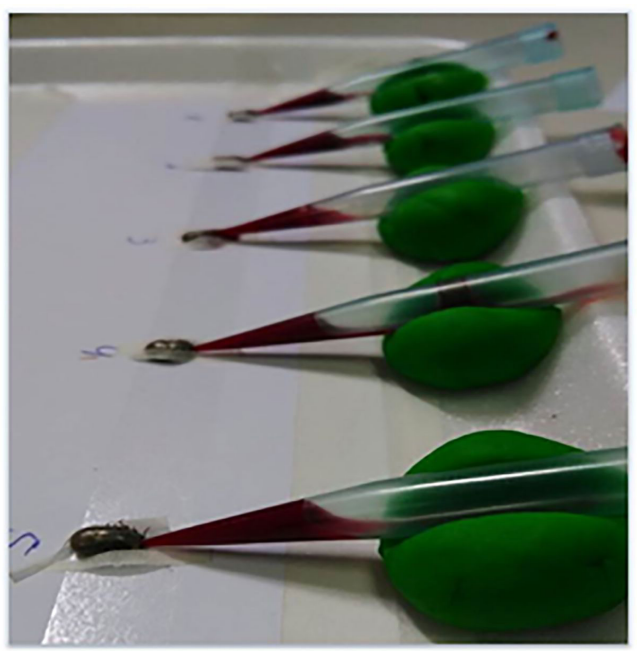

Figure 1. Artificial feeding system of Rhipicephalus sanguineus s. l. using plastic tips with dog's blood infected with Trypanosema rhipicephalis.

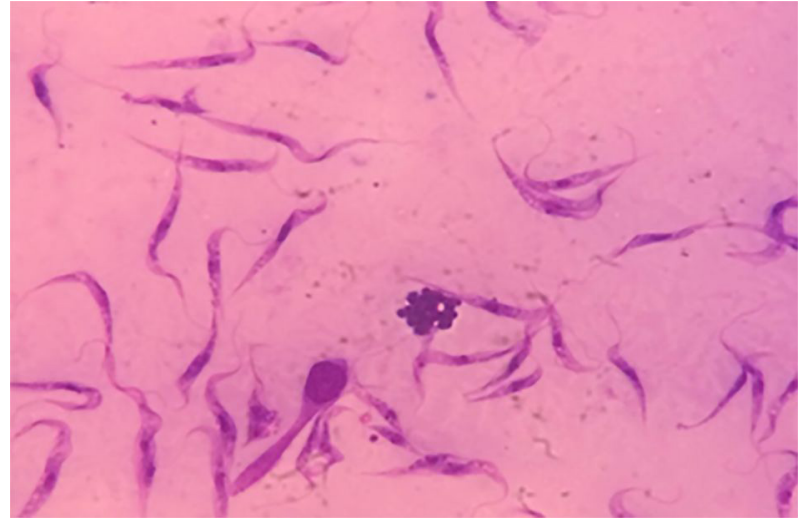

Figure 2. Epimastigote evolutionary forms of Trypanosoma rhipicephalis on tick hemolymph smear Rhipicephalus sanguineus s. l., Giemsa stained 10\%, 100X magnification.

The daily posture was collected and organized in pools of each female per day of laying. Eggs were separated into three groups, the first for egg PCR, the second for hatching and larval PCR, and the third group for isolation of eggs in cell culture.

The DNA from the pool of macerated eggs, larvae, and infected females used in the experiment were extracted using the phenol-phenol/chloroform method previously described (Santolin etal., 2013). During each extraction battery, a blank sample was extracted along with the test samples as procedural control. A conventional Polymerase Chain Reaction (PCR) was performed to detect the presence of the 24S rDNA Trypanosomatid gene, following the protocol of the original article (Souto et al., 1999). Two positive samples (Trypanosoma amblyomii) and two negative samples (ultrapure water) were used during the PCR reaction.

\section{Results}

The authors were successful in infecting $R$. sanguineus s. l. with T. rhipicephalis, a species recently described in $R$. microplus by Marotta et al. (2018). The ticks $R$. sanguineus s. l. were infected by artificial feeding, and epimastigote and amastigote forms (Figure 2) of T. rhipicephalis were recovered from the hemolymph. The morphological forms observed were pleomorphic, such as those observed in in vitro cultures isolated from Rio de Janeiro native ticks, previously described by Marotta et al. (2018). 
Evaluation of the presence of DNA in experimentally infected females showed all positive test group samples. By hemolymph test, tick number 7 showed epimastigote evolutionary forms of T. rhipicephalis.

The evaluation of DNA presence in the macerated eggs of experimentally infected ticks showed two positive PCR samples as well as the evaluation of the presence of DNA in macerated larvae, which presented one positive sample. The macerated eggs of the control G1 did not present positive bands by PCR. The PCR positive egg pool samples were from two G2 test females, one from the 4th to 6th DPI of tick number 4 and the other from the 4th to 6th DPI of tick number 6. The PCR positive larval pool sample also belonged to tick number 6 on the 6 th to 8th DPI.

\section{Discussion}

This study describes for the first time how the tick Rhipicephalus sanguineus s. l. can be infected with u T. rhipicephalis sing artificial feeding. The original description of T. rhipicephalis and preliminary studies conducted by Marotta et al. (2018) indicate its phylogenetic proximity to the KG1 species described by Thekisoe et al. (2007). Trypanosoma KG1 was isolated from naturally infected Haemaphysalis hystricis ticks in Japan (Thekisoe et al., 2007). The morphological and phylogenetic proximity between T. rhipicephalis and Trypanosoma KG1 seems to be related to the fact that it is also isolated from naturally infected ticks.

Another species with phylogenetic proximity to T. rhipicephalis is the species T. caninum isolated from an axenic culture of the intact skin of a domestic dog captured in different states of Brazil, including Rio de Janeiro (Madeira et al., 2014). Although the T. caninum vector is not yet known, it is possible that it is transmitted by ticks which then justifies the phylogenetic proximity between T. rhipicephalis and T. caninum. T. rhipicephalis has not been found to infect or cause any evidence of clinical signs in animals; there is a possibility that T. rhipicephalis has bovines as a mammalian host because tick $R$. microplus infests this species preferentially.

Although most Trypanosoma species are transmitted by hematophagous insects, ticks also appear to be likely vectors of some species of this genus (Madeira et al., 2014), (Kaufer et al., 2017), (Krige et al., 2019). In Brazil, a trypanosomatid with morphological characteristics similar to Trypanosoma theileri is naturally found in R. microplus and reported as nonpathogenic for cattle and usually transmitted by tabanids (Martins et al., 2008), (Ribeiro et al., 1988; Brum et al., 2012).

The T. rhipicephalis species in the present study showed biological characteristics compatible with other protozoa of the genus Trypanosoma, and evolutionary forms without visible free flagella in axenic cultures were seen. Recently, Barros et al. (2015) described aflagellar epimastigote forms in $T$. caninum confirmed by electron microscopy.

These results suggest that $R$. sanguineus s. l. may interact with the agent, considering its presence in the hemolymph. The present study also suggests the possible transovarial transmission of the protozoan by the tick $R$. sanguineus s. l. Transovarian transmission is a very significant mechanism for maintaining T. rhipicephalis in the environment and says a lot about its propagation and maintenance in the next generation of ticks.

R. sanguineus is a three-host life cycle species and is a competent disseminator of disease-causing microorganisms between infected and uninfected animal hosts (Dantas-Torres et al., 2013); (Sonenshine \& Roe, 2014). The one-host tick R. microplus also takes three blood meals; however, feeding is restricted to the same host, making parasites ingested by one-host tick dependent on transovarial transmission for successful circulation (Kahl, 2018).

This study contributes a research tool for future studies on the possible elucidation of the T. rhipicephalis biological cycle and the involvement of the tick $R$. sanguineus s. $l$.

\section{Conclusion}

Experimental infection through artificial feeding proved to be an adequate tool to study the interaction of T. rhipicephalis in $R$. sanguineus s. $l$. The results indicate a possible transovarial transmission of T. rhipicephalis by R. sanguineus s. l., as well as its interaction with the protozoan. 


\section{Acknowledgements}

We would like to express our gratitude to Prof. Thaís Ribeiro Correia Azevedo for providing the Rhipicephalus sanguineus sensu lato ticks, used in this article.

To the Coordenação de Aperfeiçoamento de Pessoal de Nivel Superior and Fundação Carlos Chagas Filho de Amparo à Pesquisa do Estado do Rio de Janeiro for financial support and for the post-doctoral scholarship to the second author.

We would like to express our gratitude to the Fundação Carlos Chagas Filho de Amparo à Pesquisa do Estado do Rio de Janeiro for financial support for the Scientific Iniciation scholarship for the first author.

\section{References}

Barros, J. H., Toma, H. K., \& Fatima Madeira, M. (2015). Molecular study of Trypanosoma caninum isolates based on different genetic markers. Parasitology Research, 114(2), 777-783. http://dx.doi.org/10.1007/s00436-0144291-0. PMid:25566771.

Bell-Sakyi, L., Zweygarth, E., Blouin, E. F., Gould, E. A., \& Jongejan, F. (2007). Tick cell lines: tools for tick and tick-borne disease research. Trends in Parasitology, 23(9), 450-457. http://dx.doi.org/10.1016/j.pt.2007.07.009. PMid:17662657.

Brum, I., Silva, A., Oliveira, C., Bastiani, F., Rosa, L., \& Monteiro, S. (2012). Trypanosoma theileri in cattle herd of Rio Grande do Sul State, Brazil. Comparative Clinical Pathology, 21(2), 197-199. http://dx.doi.org/10.1007/ s00580-011-1261-0.

Burgdorfer, W., Schmidt, M. L., \& Hoogstraal, H. (1973). Detection of Trypanosoma theileri in Ethiopian cattle ticks. Acta Tropica, 30(4), 340-346. PMid:4149680.

Chabaud, A. (1950). Artificial feeding of ticks. Annales de Parasitologie Humaine et Comparee, 25(1-2), 42-47. http:// dx.doi.org/10.1051/parasite/1950251042. PMid:13181220.

Dantas-Torres, F., Latrofa, M. S., Annoscia, G., Giannelli, A., Parisi, A., \& Otranto, D. (2013). Morphological and genetic diversity of Rhipicephalus sanguineus sensu lato from the New and Old Worlds. Parasites \& Vectors, 6(1), 213-213. http://dx.doi.org/10.1186/1756-3305-6-213. PMid:23880226.

Hoare, C. (1972). The trypanosomes of mamals. Oxford: Blackwell Scientific Publication. (749 p.).

Kahl, O. (2018). Hard ticks as vectors-some basic issues. Wiener Klinische Wochenschrift, 130(15-16), 479-483. http://dx.doi.org/10.1007/s00508-018-1360-x. PMid:30006758.

Kaufer, A., Ellis, J., Stark, D., \& Barratt, J. (2017). The evolution of trypanosomatid taxonomy. Parasites \& Vectors, 10(1), 287. http://dx.doi.org/10.1186/s13071-017-2204-7. PMid:28595622.

Krige, A. S., Thompson, R. C. A., \& Clode, P. L. (2019). 'Hang on a Tick' - Are ticks really the vectors for australian trypanosomes? Trends in Parasitology, 35(8), 596-606. http://dx.doi.org/10.1016/j.pt.2019.05.008. PMid:31229455.

Madeira, M. F., Almeida, A. B. P. F., Barros, J. H. S., Oliveira, T. S. F., Sousa, V. R. F., Alves, A. S., Miranda, L. F., Schubach, A. O., \& Marzochi, M. C. (2014). Trypanosoma caninum, a new parasite described in dogs in Brazil: aspects of natural infection. The Journal of Parasitology,100(2), 231-234. http://dx.doi.org/10.1645/13-297.1. PMid:24328788.

Marotta, C. R., Santos, P. N., Cordeiro, M. D., Matos, P. C. M., Barros, J. H. D. S., Madeira, M. D. F., Bell-Sakyi, L. \& Fonseca, A. H. (2018). Trypanosoma rhipicephalis sp. nov.(Protozoa: Kinetoplastida) isolated from Rhipicephalus microplus (Acari: Ixodidae) ticks in Rio de Janeiro, Brazil. Parasitology Open, 4(2), 1-8. https://doi.org/10.1017/ pao.2017.17.

Martins, J. R., Leite, R. C., \& Doyle, R. L. (2008). Tripanosomatides like Trypanosoma theileri in the cattle tick Boophilus microplus. Revista Brasileira de Parasitologia Veterinária, 17(2), 113-114. http://dx.doi.org/10.1590/ S1984-29612008000200010. PMid:18823581.

Morzaria, S. P., Latif, A. A., Jongejan, F., \& Walker, A. R. (1986). Transmission of a Trypanosoma sp. to cattle by the tick Hyalomma anatolicum anatolicum. Veterinary Parasitology, 19(1-2), 13-21. http://dx.doi.org/10.1016/03044017(86)90026-9. PMid:3962154.

Ribeiro, M. F. B., Lima, J. D., \& Guimarães, A. M. (1988). Ocorrência de Trypanosoma theileri, Laveran 1902, em Boophilus microplus, no Estado de Minas Gerais. Arquivo Brasileiro de Medicina Veterinária e Zootecnia 40(1), 65-68.

Santolin, I. D. A. C., Famadas, K. M., \& McIntosh, D. (2013). Detecção e identificação de espécies de Rickettsia em carrapatos coletados de aves silvestres no Brasil pela PCR-RFLP. Revista Brasileira de Medicina Veterinária, 35(Supl. 2), 68-73.

Sonenshine, D. E., \& Roe, R. M. (2014). Biology of ticks (Vol. 1, 447 p.). New York: Oxford University Press.

Souto, R. P., Vargas, N., \& Zingales, B. (1999). Trypanosoma rangeli: Discrimination from Trypanosoma cruzi based on a variable domain from the Large Subunit Ribosomal RNA Gene. Experimental Parasitology, 91(4), 306-314. http://dx.doi.org/10.1006/expr.1998.4380. PMid:10092474. 
Thekisoe, O. M. M., Honda, T., Fujita, H., Battsetseg, B., Hatta, T., Fujisaki, K., Sugimoto, C., \& Inoue, N. (2007). A trypanosome species isolated from naturally infected Haemaphysalis hystricis ticks in Kagoshima Prefecture Japan. Parasitology, 134(7), 967-974. http://dx.doi.org/10.1017/S0031182007002375. PMid:17306058.

Valim, J. R. A., Rangel, C. P., Baêta, B. A., Ribeiro, C. C., Cordeiro, M. D., Teixeira, R. C., Cepeda, P. B., \& Fonseca, A. H. (2017). Using plastic tips in artificial feeding of Rhipicephalus sanguineus sensu lato (Acari: Ixodidae) females. Revista Brasileira de Parasitologia Veterinária, 26(1), 110-114. http://dx.doi.org/10.1590/s1984-29612017008. PMid:28327880. 